\title{
MIGRATION OF IRON AND ALUMINUM FROM DIFFERENT COOKWARES TO FABA BEAN AFTER COOKING CYCLES AND STORAGE REFRIGERATED
}

\author{
Abdel Razeka, T, M. ${ }^{(1)}$; Kishk, Y. F. M. ${ }^{(2)}$; Khalil, N. S. A. M. ${ }^{(3)}$ \\ and Shehtaa, Attia. M.
}

1) Department of Enviromental Basic Sciences Institute for Environmental Studies and Research, Ain Shams University 2) Department of Food Scienc,Faculty of Agriculure, Ain Shams University 3) Regional Center for Food and Feed, Agricultural Research Center

\begin{abstract}
Metals supply for humans is fullfiled from food stuffs. This process is affectd by many factore i.e. cooking, packaging and handling. The aim of this work is to investigate the migration of iron and aluminum from cookware to cooked faba bean and we choosed faba bean because it high content of iron metal and it need long time for cooking. Cookwares used for the experiment were aluminum, stainless steel and enameld steel. Iron and aluminum metals were analyzed in faba bean before and after cooking for three cycles and upon storage for one week. Results revealed that aluminum

migrated from aluminum cookware to cooked faba bean as it was increased from 22.29 to $43.2 \mathrm{mg} / \mathrm{kg}$ in faba bean at the second cooking cycle. For other cookwares no migration for aluminum metal after cooking. Also iron metal migrated from all cookwares to cooked faba bean, iron migrated from aluminum cookware to cooked faba bean as it was increased from 53.5 to $66.96 \mathrm{mg} / \mathrm{kg}$ at the second cooking cycle. In case of enameled and stanless steel cookwares iron migrated as it was increased from 53.5 to $115.5 \mathrm{mg} / \mathrm{kg}$ at the third cooking cycle in enameld cookware and increased from 53.5 to 77.3 $\mathrm{mg} / \mathrm{kg}$ at the first cooking cycle in stainless steel cookware. Study the migration of iron and aluminum after storage for 7 days at 3oc the results indicated the occurrence of the migration of iron and aluminum metals in some cooking cycles and decreasing in some other cooking cycles.
\end{abstract}

Key words: Migration; Elements; Cookwares. 
J. Environ. Sci.

Institute of Environmental Studies and Research - Ain Shams University

\section{INTRODUCTION}

There are many accusations of cooking utensils for metals migration to foods. It is noticeable that the cooking utensils which are made from aluminum, iron, pottery, stainless steel are containing metals such as $\mathrm{Al}$ and Fe. Migration of elements from cookwares to food depends on the $\mathrm{pH}$ of food, length of cooking period and type of cookware (Grger, 1985).( Parkar and Rakesh, 2014) studied the migration of iron and aluminum from packaging materials to canned foods under different conditions of temperature, acidity and storage period. The results show an increase of iron and aluminum concentration. (Arora, 2000) mentained that the addition of some acidic substances such as tomatoes and dates juice is the reason of the migration of the iron content from the packaging materials. The study was based on the type of cookwares, the number of cooking cycles and storage period in the same cookware. (Lisiewska et al., (2008) studied the content of $\mathrm{P}, \mathrm{K}, \mathrm{Ca}, \mathrm{Mg}, \mathrm{Na}, \mathrm{Fe}, \mathrm{Cu}, \mathrm{Mn}, \mathrm{Cr}$, and $\mathrm{Ni}$ before and after ashing on the beans food and storage for 12 months at $30 \mathrm{oc}$, increasing the content of the elements using traditional cooking.

Studies have shown that nature of cookwares, cooking process, storage can increase trace metal level in food. Heavy metals are potential environmental contaminants with the capabilities of causing human health problems if present in food at high concentration, the type of cooking utensil used may contribute some considerable amount of trace elements into food by way of leaching (Nnorom, 2007). High Al content was found in the brain of persons with Alzheimer 's disease, and as food is actually the primay source 
of $\mathrm{Al}$ intake for humans (soniet al., 2001), Al migration from food contact materials is nowadays of great concern, Industrial processes, food preparation and various sources of drinking water may be exposed to the toxic effects of metals (Klasen, 1990).(Jarup 2003; Sathawaraet al., 2004, ) reported that heavy metals in general are not biodegradable, have a long biological half-life and also the possibility of accumulation in various organs of the body, leading to side effects undesirable. Increasing concentration of trace elements in the body may cause disorders related to the bones, brain and blood. Ingestion of food is a clear way of exposure to metals, and not only because many of the minerals and natural elements of the food but also because of environmental pollution and contamination during processing. (Damont et al., 2012) studied the effect of $\mathrm{pH}$, the nature of the acid and temperature on immigration trace elements of ceramic deal with 18 glass coating available commercially. Besides lead and cadmium, migration of toxic elements and other such as aluminum, boron, barium, cobalt, chromium, copper, iron, lithium, magnesium, manganese, nickel, antimony, tin, strontium, titanium, vanadium, zinc and zirconium in order to evaluate their potential health risks. At low $\mathrm{pH}(2<\mathrm{pH}<3)$, and the nature of the acid plays an important role.Citric and malic acid seems to be more aggressive on the glaze than smooth surface of acetic acid with the exception of aluminum, barium, chromium, iron and magnesium. Dynamic migration between $\mathrm{pH} 2$ and 3 degrees in the acetic acid from these exceptions is more exponential while other elements of linear regression been decreasing. In ceramics used in this study ( fired in 900oc), it observed a linear relationship between migration and temperature.Immigration seen from the free elements toxic steel pots 
cooking polished to unconditional food the cooking in solution is suitable for the connection food if allowed to emigrate from boron levels, fluorine cobalt and nickel exceed 2.5, 0.5, 1.0 and $1.0 \mathrm{mg} / \mathrm{L}$, respectively (Gioevaya et al., 1982).

This work aims at studying the migration of iron and aluminum metals from aluminum, enameld and stainless steel cookwares to fababean after three cooking cycles and storage for 7 days.

\section{MATERIALS AND METHODS}

\section{1- Materials:}

A- Cookwares: Three kinds of cookwares were used in the study those were aluminum, stainless steel andenameld cookwares. Before each use, all utensils were thoroughlywashed by hot water and detergent, rinsed well with tap water and air dried.

B- Faba bean: Faba bean was purchased from local market at Sharkia governorate, Egypt. Including (local faba bean ).

C- Chemicals and reagents: All chemicals, including nitric acid (69\%, Honeywell ), perchloric acid (70\%, Oxford), stock standards (Merck, 1000 $\mathrm{mg} / \mathrm{L}$ ) for $\mathrm{Fe}$ and $\mathrm{Al}$ were commercially purchased. Deionized water was obtained from Millipore unit made in france.

\section{METHODS}

1) Preparation of sample: Using tap water and fixed amount of faba bean (1 $\mathrm{kg}$ ) were cooked in three types of utensils which are aluminum, stainless steel and enameld cookwares. Faba bean was cooked about 8 hours in the 
three utensils and in the same utensil three cycles, then it was stored at 3oC 7 days with adding citric acid with random way.A homogenized sample was completely dried over night in an air oven at $1050 \mathrm{C}$, then subjected to metal analysis

2) Elemental analysis: Metals in this study were analysed using Inductively coupled plasma (ICP) (Optima 2000 Dv made in U.S.A) according to official method (AOAC, 2012).

3) $\mathrm{pH}$ of cooked food: Using Metrohm $\mathrm{pH}$ meter (thermo made in U.S.A), $\mathrm{pH}$ of faba bean was measured after cooking, cooling, homogenization.The $\mathrm{pH}$ of the resulting solution was measured after making the appropriate calibration of the $\mathrm{pH}$ meter using to bracketing buffer solutions $(\mathrm{pH} 4$ and $\mathrm{pH} 7)$.

\section{RESULT AND DISSCUTION}

In the current work, a precise model was used to investigate the possible migration of $\mathrm{Al}$ and $\mathrm{Fe}$ metals from cookwares to faba bean. Thus, after cooking and after storing. Faba bean was analyzed for metal concentration as shown in tables (1-3).

Table (1), presented the migration of $\mathrm{Fe}$ and $\mathrm{Al}$ metals from aluminum cookware to faba bean after cooking three cycles and after storing for 7 days. As showen in table (1) results pointed out that it was happened migration for iron metal as it was increased from 53.5 to $60.6 \mathrm{mg} / \mathrm{kg}$ after cookingwith a statistically significant at differences $(\mathrm{p}<0.05)$ and from 60.6 to 60.87 after storing with non statistically significant in cycle one, iron was increased from 53.5 to $66.96 \mathrm{mg} / \mathrm{kg}$ after cooking with non significant at differences ( $\mathrm{p}$ > 
0.05) and decreased from 66.96 to $62.45 \mathrm{mg} / \mathrm{kg}$ after storingwith a statistically significantat differences $(\mathrm{p}<0.05)$ in cycle two, iron was increased from 53.5 to $57.3 \mathrm{mg} / \mathrm{kg}$ after cookingwith a statistically significant at differences $(\mathrm{p}<0.05)$ and it was increased from 57.3 to 63.14 $\mathrm{mg} / \mathrm{kg}$ after storing with a statistically significanat differences $(\mathrm{p}<0.05)$ in cycle three. Aluminum metal was increased from 22.29 to $26.4 \mathrm{mg} / \mathrm{kg}$ after cooking with non significant at differences ( $\mathrm{p}>0.05$ )and from 26.4 to 30.98 $\mathrm{mg} / \mathrm{kg}$ after storingwith a statistically significant at differences $(\mathrm{p}<0.05)$ in cycle one, aluminum was increased from 22.29 to $43.2 \mathrm{mg} / \mathrm{kg}$ after cookingwith a statistically significantat differences $(p<0.05)$ and decreased from 43.2 to $40.07 \mathrm{mg} / \mathrm{kg}$ after storing with non significant at differences ( $\mathrm{p}<0.05$ ) in cycle two, aluminum was increased from 22.29 to $31.6 \mathrm{mg} / \mathrm{kg}$ after cookingwith a statistically significant at differences $(\mathrm{p}<0.05)$ and from 31.6 to $36.87 \mathrm{mg} / \mathrm{kg}$ after storing with a statistically significant at differences ( $\mathrm{p}<0.05$ )in cycle three. (Cheng and Brittin, 1991) confirmed other previous research that foods cooked in iron utensils were greater in iron content than foods cooked in non-iron utensils. (Greger et al.,1985) reported that tomatoes heated in aluminum pans for a few minutes accumulated only $0.02-0.03 \mathrm{mg}$ $\mathrm{Al} / 100 \mathrm{~g}$ serving, while tomato sauces cooked for 3 hours in aluminum pans accumulated 5.7mg Al/100g serving. (Zhan et al., 2015) studied the migration of metals from ceramic pan to acidic foods and storage food in short time (24h) at $20-40 \mathrm{oC}$ the migration of metals was failed, but in long time $(600 \mathrm{~h})$ the migration of metals was increased. 
Table (1): Concentration of $\mathrm{Fe}$ and $\mathrm{Al}$ metals in faba bean before and after cooking in aluminum utensil for three cycles and after storing for 7 days.

\begin{tabular}{|c|c|c|c|}
\hline Cooking cycles & Fe & Al & $\mathrm{pH}$ \\
\hline \hline Raw faba bean & $53.5 \mathrm{~d} \pm 0.4$ & $22.29 \mathrm{~d} \pm 2.19$ & 6.3 \\
\hline $\begin{array}{c}\text { Cycle one after } \\
\text { cooking }\end{array}$ & $60.6 \mathrm{bc} \pm 2.2$ & $26.4 \mathrm{~d} \pm 1.1$ & 5.67 \\
\hline $\begin{array}{c}\text { cycle one after } \\
\text { storing for 7 days }\end{array}$ & $60.87 \mathrm{bc} \pm 1.97$ & $30.98 \mathrm{c} \pm 0.88$ & 4.2 \\
\hline $\begin{array}{c}\text { Cycle two after } \\
\text { cooking }\end{array}$ & $66.96 \mathrm{a} \pm 1.26$ & $43.2 \mathrm{a} \pm 1.4$ & 5.6 \\
\hline $\begin{array}{c}\text { Cycle two after } \\
\text { storing for 7 days }\end{array}$ & $62.45 \mathrm{~b} \pm 0.75$ & $40.07 \mathrm{ab} \pm 0.57$ & 4.5 \\
\hline $\begin{array}{c}\text { Cycle three after } \\
\text { cooking }\end{array}$ & $57.3 \mathrm{c} \pm 1.0$ & $31.6 \mathrm{c} \pm 2.4$ & 5.65 \\
\hline $\begin{array}{c}\text { Cycle three after } \\
\text { storing for 7 days }\end{array}$ & $63.14 \mathrm{~b} \pm 0.74$ & $36.87 \mathrm{~b} \pm 1.67$ & 4.02 \\
\hline \hline
\end{tabular}

Means of the same letter(s) in the same column are not significantly different ( $p>$ $0.05)$.

Raw faba bean mean :faba bean before cooking.

Table (2), study the migration of $\mathrm{Fe}$ and $\mathrm{Al}$ metals from enameld cookware to faba bean after cooking three cycles and after storing for 7 days. As showen in table (2) results pointed out that it was happened migration for iron metal as it was increased from 53.5 to $54.6 \mathrm{mg} / \mathrm{kg}$ after cooking with non significant at differences ( $\mathrm{p}>0.05$ ) and from 54.6 to 55.12 after storing with non significant at differences ( $\mathrm{p}>0.05)$ in cycle one, iron was increased from 53.5 to $77.6 \mathrm{mg} / \mathrm{kg}$ after cookingwith a statistically significant at differences $(\mathrm{p}<0.05)$ and decreased from 77.6 to $63.19 \mathrm{mg} / \mathrm{kg}$ after storing with a statistically significantat differences $(\mathrm{p}<0.05)$ in cycle two, iron was 
increased from 53.5 to $115.5 \mathrm{mg} / \mathrm{kg}$ after cooking with a statistically significant at differences $(\mathrm{p}<0.05)$ and it was decreased from 115.5 to 71.3 $\mathrm{mg} / \mathrm{kg}$ after storingwith a statistically significant at differences $(\mathrm{p}<0.05)$ in cycle three. Aluminum metal was decreased from 22.29 to $10.0 \mathrm{mg} / \mathrm{kg}$ after cookingwith a statistically significantat differences $(\mathrm{p}<0.05)$ and it was increased from 10.0 to $14.8 \mathrm{mg} / \mathrm{kg}$ after storing with a statistically significant at differences $(\mathrm{p}<0.05)$ in cycle one, aluminum was decreased from 22.29 to $19.06 \mathrm{mg} / \mathrm{kg}$ after cooking with a statistically significant at differences $(\mathrm{p}<0.05)$ and decreased from 19.06 to $17.7 \mathrm{mg} / \mathrm{kg}$ after storing with non significant at differences ( $p>0.05)$ in cycle two, aluminum was decreased from 22.29 to $18.5 \mathrm{mg} / \mathrm{kg}$ after cooking with a statistically significantat differences $(\mathrm{p}<0.05)$ and from 18.5 to $13.6 \mathrm{mg} / \mathrm{kg}$ after storing with a statistically significant at differences $(\mathrm{p}<0.05)$ in cycle three, also the migration of $\mathrm{Al}$ metal was decreased due to the hydrothermal abilities and usage in the electroplating of other metals (Temidayo, 2011). (Tassi et al., 2014) studied the migration of $\mathrm{Cu}, \mathrm{Cr}, \mathrm{Cd}, \mathrm{Al}, \mathrm{Fe}, \mathrm{Mn}, \mathrm{Ni}$, and $\mathrm{Pb}$ from carbon steel cylinders to food gases and stored up to 50 day, the migration was lower for metals. (Quintaes et al., 2006) studied the migration of Fe, $\mathrm{Mg}, \mathrm{Mn}, \mathrm{Cr}, \mathrm{Ni}$, and $\mathrm{Ca}$ from Brazilian pans to rice and tomato sauce at 7 cooking cycles the result pointed out migration of the metals.A hot leach method published by the World Health Organization for determining $\mathrm{Pb}$ and $\mathrm{Cd}$ in ceramic and enameled ware was collaboratively studied in 14 laboratories. The method consisted of heating a solution of $4 \%$ acetic acid at the boil for $2 \mathrm{~h}$ in 6 samples of specially glazed ceramic ware and 6 samples 
of special enameled ware. The acid was allowed to cool and stand in contact with the ware for an additional $22 \mathrm{~h}$. At the end of the $2 \mathrm{~h}$ heating period and again at the end of the $24 \mathrm{~h}$ period, the leach solution was assayed by atomic absorption spectrophotometry for $\mathrm{Pb}$ and $\mathrm{Cd}$.The quantity of $\mathrm{Pb}$ and $\mathrm{Cd}$ released from enameled ware increased linearly with time during $7 \mathrm{~h}$ of boiling(Gould et al., 1983).

Table (2): Concentration of $\mathrm{Fe}$ and $\mathrm{Al}$ metals in faba bean before and after cooking in enameld utensil for three cycles and after storing for 7 days.

\begin{tabular}{|c|c|c|c|}
\hline \hline Cooking cycles & Fe & Al & pH \\
\hline \hline Raw faba bean & $53.5 \mathrm{e} \pm 0.4$ & $22.29 \mathrm{a} \pm 2.19$ & 6.3 \\
\hline $\begin{array}{c}\text { Cycle one after } \\
\text { cooking }\end{array}$ & $54.6 \mathrm{e} \pm 0.8$ & $10.0 \mathrm{~d} \pm 0.8$ & 5.9 \\
\hline $\begin{array}{c}\text { cycle one after } \\
\text { storing for 7 days }\end{array}$ & $55.12 \mathrm{e} \pm 0.62$ & $14.8 \mathrm{c} \pm 0.16$ & 3.9 \\
\hline $\begin{array}{c}\text { Cycle two after } \\
\text { cooking }\end{array}$ & $77.6 \mathrm{~b} \pm 0.9$ & $19.06 \mathrm{~b} \pm 0.9$ & 5.5 \\
\hline $\begin{array}{c}\text { Cycle two after } \\
\text { storing for 7 days }\end{array}$ & $63.19 \mathrm{~d} \pm 0.99$ & $17.7 \mathrm{~b} \pm 0.4$ & 4.2 \\
\hline $\begin{array}{c}\text { Cycle three after } \\
\text { cooking }\end{array}$ & $115.5 \mathrm{a} \pm 1.2$ & $18.5 \mathrm{~b} \pm 0.7$ & 5.6 \\
\hline $\begin{array}{c}\text { Cycle three after } \\
\text { storing for 7 days }\end{array}$ & $71.3 \mathrm{c} \pm 1.0$ & $13.6 \mathrm{c} \pm 0.8$ & 4.5 \\
\hline
\end{tabular}

Means of the same letter(s) in the same column are not significantly different $(\mathrm{p}>0.05)$.

Raw faba bean mean : faba bean before cooking.

Table (3), study the migration of $\mathrm{Fe}$ and $\mathrm{Al}$ metals from stainless steel cookware to faba bean after cooking three cycles and after storing for 7 days. As showen in table (3) results pointed out that the migration for iron metal as it was increased from 53.5 to $77.3 \mathrm{mg} / \mathrm{kg}$ after cookingwith a statistically significant at differences $(\mathrm{p}<0.05)$ and it was decreased from 77.3 to 56.7 
after storing with a statistically significant at differences $(\mathrm{p}<0.05)$ in cycle one, iron was increased from 53.5 to $55.7 \mathrm{mg} / \mathrm{kg}$ after cooking with non significant at differences ( $\mathrm{p}>0.05$ ) and increased from 55.7 to $66.5 \mathrm{mg} / \mathrm{kg}$ after storing with a statistically significantat differences $(\mathrm{p}<0.05)$ in cycle two, iron was increased from 53.5 to $61.97 \mathrm{mg} / \mathrm{kg}$ after cooking with a statistically significant at differences $(\mathrm{p}<0.05)$ and it was decreased from 61.97 to $57.04 \mathrm{mg} / \mathrm{kg}$ after storing with a statistically significantat differences $(\mathrm{p}<0.05)$ in cycle three. Aluminum metal was decreased from 22.29 to 19.6 $\mathrm{mg} / \mathrm{kg}$ after cooking with non significant at differences ( $\mathrm{p}>0.05)$ and from 19.6 to $12.8 \mathrm{mg} / \mathrm{kg}$ after storing with non significant at differences ( $\mathrm{p}>0.05$ ) in cycle one, aluminum was decreased from 22.29 to $14.3 \mathrm{mg} / \mathrm{kg}$ after cooking with a statistically significant at differences $(\mathrm{p}<0.05)$ and decreased from 14.3 to $13.8 \mathrm{mg} / \mathrm{kg}$ after storing with non significant at differences ( $p>0.05$ ) in cycle two, aluminum was decreased from 22.29 to $13.96 \mathrm{mg} / \mathrm{kg}$ after cooking with a statistically significant at differences $(\mathrm{p}<0.05)$ and from 13.96 to $12.3 \mathrm{mg} / \mathrm{kg}$ after storing with non significant differences $(\mathrm{p}<0.05)$ in cycle three, also the migration of Al metal was decreased due to the hydrothermal abilities and usage in the electroplating of other metals (Temidayo, 2011). Temidayo (2011) studied how cadmium and chromium leach into the food we eat. Results were generated from the study of the ratios of cadmium and chromium contamination of food boiled in steel and stainless steel pots using Flame Atomic Absorption Spectrophotometry (FAAS). Cadmium was leached from new stainless steel and not detected in new steel pots, but for the old and very old stainless steel pots and steel pots, which 
gave $0.093 \pm 0.02 \mu \mathrm{g} / \mathrm{g}$ and $0.045 \pm 0.020 \mu \mathrm{g} / \mathrm{g}$ for old and very old steel pots, while $0.079 \pm 0.01 \mu \mathrm{g} / \mathrm{g}$ and $0.092 \pm 0.01 \mu \mathrm{g} / \mathrm{g}$ for old and very old stainless steel pots, cadmium leached beyond the control concentration. No leaching of chromium was detected in new stainless pots and steel pots, as well as, old and very old pots. (Buculei et al., 2011) studied the migration of $\mathrm{Cu}, \mathrm{Al}, \mathrm{Mn}$, $\mathrm{Fe}, \mathrm{Zn}$, and $\mathrm{Cr}$ from packaging in beer during storage 6 months at 26-28 co, the content of metals was decreased.

Table (3): Concentration of $\mathrm{Fe}$ and $\mathrm{Al}$ metals in faba bean before and after cooking in stainless steel utensil for three cycles and after storing for 7 days.

\begin{tabular}{|c|c|c|c|}
\hline Cooking cycles & Fe & Al & pH \\
\hline \hline Raw faba bean & $53.5 \mathrm{~d} \pm 0.4$ & $22.29 \mathrm{a} \pm 2.19$ & 6.3 \\
\hline $\begin{array}{c}\text { Cycle one after } \\
\text { cooking }\end{array}$ & $77.3 \mathrm{a} \pm 1.5$ & $19.6 \mathrm{ab} \pm 0.8$ & 5.7 \\
\hline $\begin{array}{c}\text { cycle one after } \\
\text { storing for 7 days }\end{array}$ & $56.7 \mathrm{~d} \pm 1.5$ & $12.8 \mathrm{~b} \pm 1.0$ & 4.2 \\
\hline $\begin{array}{c}\text { Cycle two after } \\
\text { cooking }\end{array}$ & $55.7 \mathrm{~d} \pm 0.6$ & $14.3 \mathrm{~b} \pm 0.7$ & 5.8 \\
\hline $\begin{array}{c}\text { Cycle two after } \\
\text { storing for 7 days }\end{array}$ & $66.5 \mathrm{~b} \pm 1.07$ & $13.8 \mathrm{~b} \pm 0.68$ & 4.1 \\
\hline $\begin{array}{c}\text { Cycle three after } \\
\text { cooking }\end{array}$ & $61.97 \mathrm{c} \pm 1.03$ & $13.96 \mathrm{~b} \pm 0.3$ & 6.00 \\
\hline $\begin{array}{c}\text { Cycle three after } \\
\text { storing for 7 days }\end{array}$ & $57.04 \mathrm{~d} \pm 0.9$ & $12.3 \mathrm{~b} \pm 0.3$ & 4.06 \\
\hline \hline
\end{tabular}

Means of the same letter(s) in the same column are not significantly different $(\mathrm{p}>$ $0.05)$.

Raw faba bean mean : faba bean before cooking.

\section{CONCLUSION}

The results of the study showed that the iron metal was migrated from all the cooking utensils and the aluminum element was transferred from the 
aluminum cookware onlyand migration in some cycles and no migration in other cycles after storing for 7 dyas.

\section{REFERENCES}

AOAC (2012): Official Methods of Analysis. 19 th Ed., Association Official Analytical Chemists, Washington D.C.

Arora, A.; (2000): Total and ionisable iron content from vegetables as influenced bycooking in iron utensil.Journal of Food Science and Technology, 37(1), 64-66.

Buculei, A.; Lonescua, M.; Rebenciue, L.; Constantinescu, G.; Dabisa, A.; (2011): Astudy of metal migration from packaging in beer during storage. Journal of Agroalimentary Processes and Technology, 17 (3), 219-227.

Cheng, Y.J., and Brittin, H.C. (1991). Iron in food: Effect of continued use of iron cookware. J. Food Sci. 56 (2) 584-585.

Demont, M., Boutakhrit, K.,Fekete, V.,Bolle, F., Van Loco, J.(2012). Migration of 18 trace elements from ceramic food contact material: Influenceof pigment, $\mathrm{pH}$, nature of acid and temperature. Food and Chemical Toxicology 50 (2012) 734-743.

Gioevaya, V.L.; Krylova, M.L.; Zenina, G.V.;Vankova,T.A.;(1982): Methodical Schemes for a Health and Chemical Study of Enameled-Steel Cooking Utensil .Analytical Abstracts, 99, 45-51.

Gould JH, Butler SW, Boyer KW, Steele EA (1983). Hot leaching of ceramic and enameled cookware: collaborative study. J AssocOff Anal Chem. 66(3):610-9.

Greger, J.L.;(1985): Aluminum content of the American Diet. Food Technology, 39, 73-80.

Greger, J.L., Goetz, W., and Sullivan, D. (1985). Aluminum levels in foods cooked and stored in aluminum pans, trays and foil. J. Food Protect. 48 (9), 772-777. 
Jarup, L.; (2003): Hazards of heavy metal contamination. British Medical Bulletin, 68 167-182.

Klassen, C. D.; (1990): Heavls and heavy metal antagonists.Goodman Publications, London.

Lisiewska, Z.; Słupski,J.; Kmiecik, W.;Gebczynski, P.; (2008): Availability of essential and trace elements in frozen leguminous vegetables prepared for consumption accordingto the method of pre-freezing processing. Food Chemistry, 106, 576-582.

Nnorom, I.C.; (2007): Trace of heavy metal level of some bouillon cubes and food condiments readily consumed in Nigeria. Packaging Journal Nutration, 6(2), 122-127.

Parkar, JandRakesh, M (2014): Leaching of elements from packaging material into canned foodsmarketed in India, Food Control, 40, 177-184.

Quintaes, K. D; Amaya Farfan, J.; Tomazini, F. M.;Morgano, M. A.; (2006): Mineral migration from stainless steel, castiron and soapstone (steatite) Brzilian pans to food. Archivcos latinoamericanos de nutricion. 56(3), 275-281.

Sathawara, N. G.; Parikh, D. J.; \&Agarwal, Y. K.; (2004): Essential heavy metals in environmental samples from western India.Bulletin of Environmental Contamination and Toxicology, 73, 756-761.

Soni, M. G.; Lucchini, R.; Vanrensborgs, Taylor. A.; (2001): Safety evaluation of dietary aluminum. Toxicol pharmacol. 33, 66-79.

Tassi, F.; Capesshiacci, F.; Vaselli, O.; (2014): Migration processes of metal elements from carbon steel cylinders to food gases. Packaging Technology and Science, 27, (10), 787-797.

Temidayo, O.A. (2011). Cadmium and Chromium Determination in Food Boiled in Steel and Stainless Steel Pots. Learning Publics Journal of Agriculture and Environmental Studies 2 (2), 45-50.

Zahan-Hue Dong.; Li-Xin Lu.; Zhi- Ganglui.; (2015): Migration model of toxic metals from ceramic food contact materials into acid food. Packaging Technology and Science, 28 (6), 545-556. 


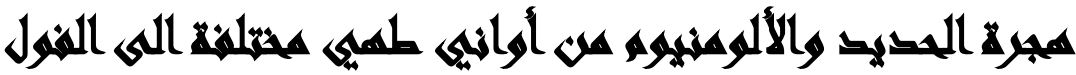

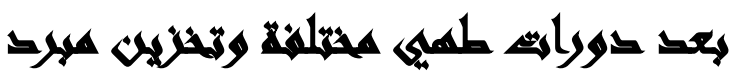

\section{$[r]$}

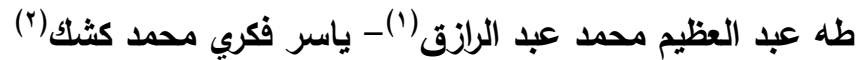

$$
\begin{aligned}
& \text { ناصر شعبان على محمد (")-- عطيه محمد شحته عطيه }
\end{aligned}
$$

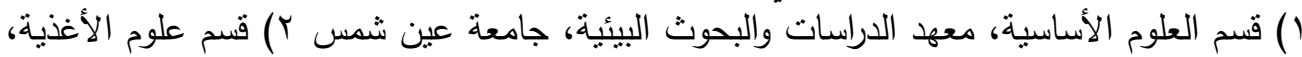

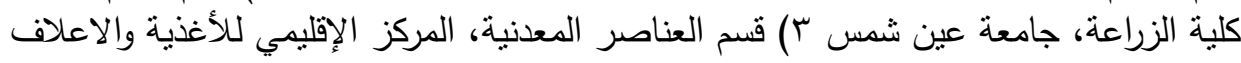

\section{المهريطلص}

يهدف هذا البحث الى دراسة هجرة الحديد والألومنيوم من أواني الطهي المختلفة الى الفول

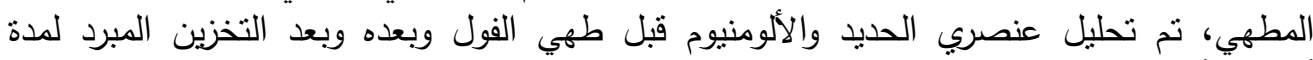

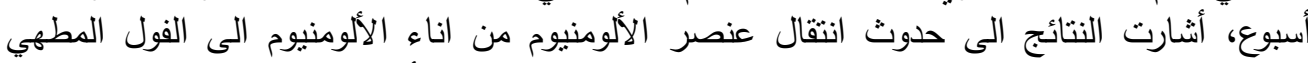

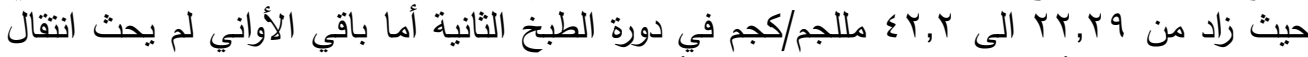

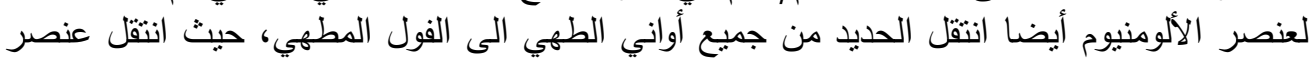

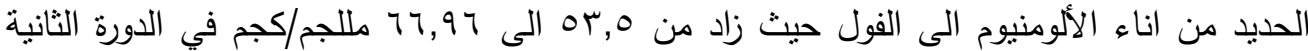

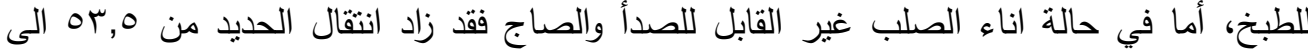

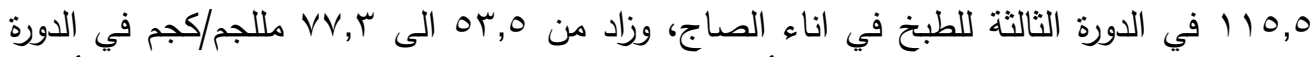

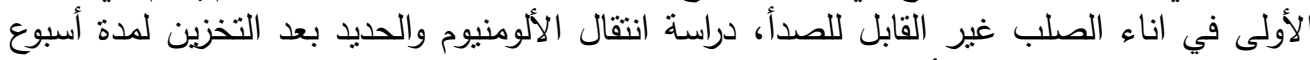

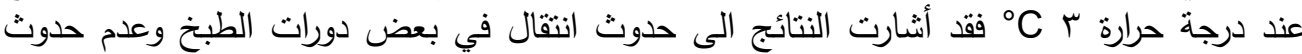

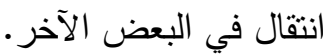

